\title{
WADAH AKTIVITAS TEMPORER DI RAWA BUAYA
}

\author{
Adelia Putri Octavini ${ }^{1)}$, Dewi Ratnaningrum ${ }^{2)}$ \\ 1)Program Studi S1 Arsitektur, Fakultas Teknik, Universitas Tarumanagara, adelia.octavini@gmail.com \\ 2)Program Studi S1 Arsitektur, Fakultas Teknik, Universitas Tarumanagara, dewitrionotasman@gmail.com
}

Masuk: 10-01-2020, revisi: 14-02-2020, diterima untuk diterbitkan: 09-05-2020 (doi: 10.24912/stupa.v2i1.6882)

\begin{abstract}
Abstrak
Kehidupan masyarakat Jakarta banyak dihabiskan di tempat tinggal (first place) dan tempat bekerja (second place). Kurangnya interaksi masyarakat di luar dua tempat tersebut membuat masyarakat merasa asing dengan lingkungan sekitarnya hingga menimbulkan prasangka dan kejahatan (Theory of Deindividuation). Manusia cenderung merasa lebih aman terhadap lingkungan sekitarnya, apabila ia dapat mengenal orang sekitarnya. Kepadatan kota Jakarta diiringi beragam aktivitas yang belum terwadahi dengan baik. Pengoptimalan ruang menggunakan sifat kesementaraan ruang terwujud dalam portabilitas arsitektur dan perencanaan program yang berfungsi mewaktukan ruang. Untuk mempertemukan masyarakat, direncanakan sebuah wadah aktivitas yang bersifat temporer yang berada di Rawa Buaya. Lingkungan ini dipilih karena memiliki keberagaman yang tinggi. Metode yang dipakai adalah metode kuantitatif dan kualitatif, yaitu berupa observasi grounded, wawancara, dan kajian literatur. Program ruang dalam bangunan ini terwujud melalui zona yang ada, yaitu Zona Temporary Event, Zona Knowledge Sharing, Zona Pocket Farming, dan Zona Komersil. Zona tersebut direncanakan untuk mempertemukan dan memicu kebutuhan antar pengguna sehingga dapat saling berinteraksi. Pengorganisasian ruang juga dibentuk melalui pendekatan teori Psikologi Sosial, yaitu Functional Distance. Bentuk bangunan terinspirasi dari metamorfosa teori Liquid Phase di Temporary City yang diwujudkan dalam bentuk cone. Kemudian bentuk denah yang melengkung mengikuti cone tadi membuat bangunan menjadi lebih dinamis. Sehingga karakter third place dapat terpenuhi, yaitu playful mood, conversation is the main activity, dan neutral.
\end{abstract}

\section{Kata kunci: arsitektur sementara; psikologi sosial arsitektur; tempat ketiga}

\begin{abstract}
The lives of many Jakarta people are spent in the residence (first place) and the workplace (second place). Lack of community interaction outside these two places makes people feel unfamiliar with the surrounding environment to cause prejudice and even crime (Theory of Deindividuation). Humans tend to feel more secure about the surrounding environment if they can get to know the people around him. The density of Jakarta is accompanied by a variety of activities that have not been properly enclosed. Spatial optimization using the planning of space temporality is manifested in the portability of architecture and program planning. To bring the community together, a temporary activity place (Tempo. Act. Place) is designed in Rawa Buaya. This site was chosen because it has a high diversity of the community. The method used is quantitative and qualitative methods, which is a grounded observation, interviews, and a literature review. The program in this building is realized through some zones, which are the Temporary Event Zone, the Knowledge Sharing Zone, the Pocket Farming Zone, and the Commercial Zone. The zone is planned to bring togetherness and trigger the needs of users so they can interact with each other. Organizing space is also formed through the approach of Social Psychology theory, namely Functional Distance. The shape of the building was inspired by the metamorphosis of the Liquid Phase theory in Temporary City which was realized in the form of cones. Then the curved floor plan following the cone made the building more dynamic. So that the third-place character that are playful mood, a conversation is the main activity, and neutral can be fulfilled.
\end{abstract}

Keywords: social psychology architecture; temporary architecture; third place 


\section{PENDAHULUAN}

Jakarta menjadi kota yang dipilih karena Jakarta merupakan kota besar dengan masyarakat yang sangat beragam. Menurut Badan Pusat Statistik (2017), Jakarta memiliki luas geografis sebesar $662,33 \mathrm{~km}^{2}$ dan jumlah penduduk mencapai lebih dari 10,37 juta jiwa pada tahun 2017. Hal ini menjadikan Jakarta sebagai kota terpadat di Indonesia. Kehidupan masyarakat Jakarta banyak dihabiskan di tempat tinggal (first place) dan tempat bekerja (second place). Kurangnya interaksi masyarakat di luar dua tempat tersebut membuat masyarakat merasa asing dengan lingkungan sekitarnya. Rasa asing tersebut dapat menimbulkan prasangka dan bahkan kejahatan di dalam suatu komunitas masyarakat (Theory of Deindividuation). Manusia cenderung akan merasa lebih aman terhadap lingkungan sekitarnya, apabila ia dapat mengenal orang sekitarnya.

Rawa Buaya adalah salah satu kecamatan di Jakarta dengan keberagaman yang tinggi. Keberagaman tersebut digolongkan secara ekonomi menjadi dua golongan yaitu golongan menengah ke bawah (low class) dan golongan atas (middle-high class). Golongan atas tidak memiliki kegiatan yang bersifat sosial sebanyak golongan menengah ke bawah. Antar dua golongan ini bahkan tidak memiliki kegiatan yang bersama yang dapat mempertemukan mereka, meskipun mereka berada di suatu lingkungan yang sama. Apabila hal ini terus berlanjut, rasa asing dari masyarakat akan terjadi hingga menimbulkan prasangka dan kejahatan (theory of deindividuation). Maka dari itu, direncanakan sebuah Wadah Aktivitas yang menggunakan konsep kesementaraan (temporariness) dan pendekatan psikologi-sosial untuk mempertemukan masyarakat antar golongan.

\section{KAJIAN LITERATUR}

Third Place adalah sebuah tempat yang dapat dikunjungi oleh publik, tanpa terkecuali. Third Place memiliki fungsi paling utama yaitu menyatukan komunitas di sebuah lingkungan (Ray Oldenburg, 1989). Dijelaskan lebih lanjut bahwa sebuah tempat yang menampilkan atau mempertemukan orang-orang secara nyata dan visual, kedepannya akan membuat lingkungan yang setiap orangnya saling mengenal. Dengan adanya kesadaran dan pengenalan terhadap orang lain, sikap individualistis akan berkurang sehingga dapat menciptakan rasa aman.

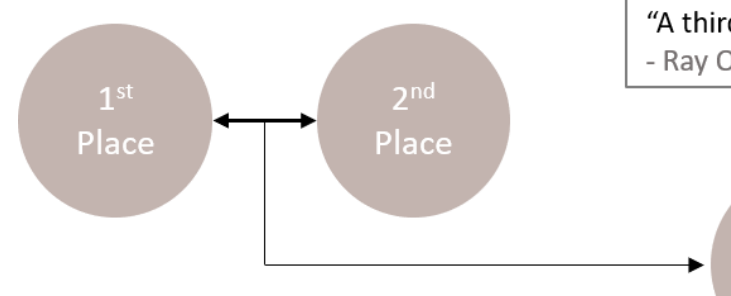

Gambar 1. Hubungan Tempat Ketiga Sumber: Penulis, 2019

Dalam merancang Third Place, Open Architecture menjadi sebuah konsep yang dapat diajukan. Guy Geier (2013) menjelaskan bahwa Open Architecture haruslah dapat dijangkau dan dipahami oleh orang orang yang terhubung dengan bangunan itu. Guy Geier memberikan studi kasus bangunan New York Times di Amerika, yang berbeda dengan bangunan lain di sekitarnya yang memiliki signage begitu mencolok hingga menutup arsitektur itu sendiri.

Kota pada dasarnya ditinggali secara bersama. Kita berbagi tempat tinggal, tempat kerja, tempat belajar secara bersama. Duncan McLaren and Julian Agyeman (2015) dalam buku Sharing Cities menjelaskan bahwa sharing (berbagi) adalah sebuah sikap sosio-kultural yang evolusioner, yang memungkinkan pengembangan dari berburu, agrikultur, perdagangan, kerajinan, dan manufaktur. Namun dengan adanya marketisasi, industrialisasi, dan konsumtivisme, kota menjadi ruang dimana bentuk sosio-kultural dari berbagi semakin melemah. 
Generasi yang paling terbuka terhadap konsep "sharing" adalah generasi milenium. Dalam buku ini dijelaskan bahwa generasi ini memiliki pemaknaan yang berbeda dibandingkan dengan orangtua dan kakek-nenek ketika seusia mereka. Pemaknaan generasi ini termasuk gaya hidup minimalis dan disownership. Sejalan dengan kenyamanan mereka dengan teknologi dan tingginya perhatian terhadap isu lingkungan, generasi millennium lebih terbuka untuk berbagi ruang dan pelayanan publik.

Berdasarkan buku psikologi sosial karya Elliot Aronson dkk. (2010), sebuah kelompok yang dapat dikatakan berhasil adalah kelompok yang terdiri dari dua orang atau lebih yang saling berinteraksi dan bergantung, dengan kebutuhan dan tujuan mereka yang saling memengaruhi mereka. Tidak hanya memiliki kebutuhan yang besar, tapi akibat adanya perasaan keinginan untuk berada di grup dengan orang yang memiliki kesamaan. Itu sebabnya orang lebih banyak yang menyukai kelompok kecil dengan kesamaan dibanding kelompok besar.

Dari hal tersebut, kita dapat menentukan aktivitas pada program rancangan kita dengan memerhatikan kelompok kecil yang ada. Seperti eksperimen yang pernah dilakukan di sebuah sekolah bernama Jigsaw Type Study Group. Eskperimen ini melibatkan beragam kepribadian orang. Mereka dibagi kelompok dengan pemberian tugas yang berbeda-beda. Karena kebutuhan masing-masing, mereka dengan sukarela menerima apa yang telah diberikan pada masing-masing orang. Dengan membagi-bagi kebutuhan itu, mereka dapat saling berusaha untuk mendapatkan kebutuhan yang ada di orang lain. Sehingga interaksi dapat terjadi.

Dalam buku ini, juga dijelaskan bahwa daya tarik (attraction) dan keakraban (propinquity) tidak hanya dipengaruhi oleh jarak secara fisik (physical distance), tetapi juga dipengaruhi oleh jarak fungsional (functional distance). Jarak fungsional ini mengacu pada aspek perancangan arsitektur. Hal iniah yang akan menentukan siapa yang akan kita temui di jalan penyebrangan. Kita juga dapat menemukan adanya interaksi antar orang yang berlalu lalang di tangga dengan orang yang sedang mengambil surat di mailbox.

Kota metropolitan memiliki beragam aktivitas yang diciptakan oleh beragamnya masyarakat yang ada di dalamnya. Permasalahan yang kerap kali ditemui di kota adalah kurangnya rencana untuk mengefisienkan penggunaan ruang. Perencanaan tersebut dapat kita perdalam dengan membawa unsur waktu.

Berbicara tentang waktu, kita akan dihadapkan oleh beberapa kemungkinan yaitu "temporer" dan "permanen". Apabila kita dapat menyatukan beberapa kegiatan dalam suatu ruang, dengan memperhitungkan unsur waktu tersebut, mengapa kita harus terus fokus terhadap "pemanensi" sebuah bangunan? Hal ini dapat kita lihat dari berlomba-lombanya manusia dalam menciptakan hal yang kekal. Seperti kutipan dari perkataan Avianti Armand (2017):

"Dalam hidup yang cuma sebentar, membangun sesuatu yang abadi, dengan material yang bisa bertahan selamanya, lalu menjadi tanda tanya besar: untuk apa? Keabadian itu seolah jaminan kepemilikan yang takkan berakhir, tapi juga monumen untuk sebuah kealpaan dan kefanaan kita."

Dalam buku The Temporary City, karya Peter Bishop dan Lesley Williams (2012), konsep kesementaraan ini dibahas dengan diberikan beberapa studi kasus. Dapatkah penggunaan temporer menjadi perwujudan akan kebutuhan ruang yang lebih dinamis dan fleksibel, dimana kota menjadi lebih responsif akan kebuhan baru yang bergantung dari pengguna?

Seorang sosiolog, Zygmunt Bauman, mengatakan bahwa di 40-50 tahun terakhir kita telah berpindah dari fase "solid" ke fase "liquid". Fase "solid" berdasarkan kepercayaan bahwa memungkinkan untuk menciptakan sebuah dunia yang sangat rasional. Perubahan hanya terlihat sementara yang dapat diselesaikan tanpa perubahan lebih lanjut. Sedangkan fase "liquid" adalah seperti cairan yang tidak dapat mempertahankan bentuknya. Kita tidak lagi percaya bahwa kesempurnaan dapat tercapai. 


\section{METODE}

Isu di Jakarta yang dibahas lebih mengarah ke isu sosial. Untuk merencanakan bangunan dengan perhatian pada isu sosial, metode yang dipakai pada penelitian ini adalah metode kualitatif. Observasi grounded dan wawancara terhadap warga dilakukan di awal penelitian, sehingga isu dan permasalahan yang ada dapat dirumuskan. Kemudian sambil beriringan dengan semua proses, kajian literatur dilakukan supaya dapat mendukung penyelesaian isu dan masalah.

Sedangkan untuk perencanaan, digunakan metode analisis-sintesis dari Christopher Alexander (1964). Setelah melakukan survey dan membuat analisis berupa tabel pohon yang menurun ke bawah, dapat diketahui perilaku antar golongan masyarakat setempat dan kegiatan yang dapat diajukan untuk diwadahi lebih baik. Kemudian, proses sintesis menghasilkan program ruang dari kondisi spesifik hingga umum yang membentuk nama proyek. Program ruang proyek dikembangkan dengan pendekatan psikologi sosial.

\section{DISKUSI DAN HASIL}

\section{Analisis Tapak}

Kawasan terpilih, Rawa Buaya, didominasi oleh bangunan dengan fungsi perumahan. Dengan adanya perumahan, bangunan nantinya masih dapat diakses oleh masyarakat nonproduktif pada waktu usia produktif sibuk bekerja, sehingga konsep third place (regulars) dapat tercapai. Pada sepanjang jalan arteri didominasi oleh fungsi industri \& perdagangan dan perkantoran, perdagangan \& jasa. Untuk fungsi industri dan perdagangan terdiri dari pabrik dan gudang penyimpanan (storage). Terdapat dua kategori ekonomi yang penulis golongkan, yaitu kategori low income dan middle-high income. Keduanya berada dalam satu kelurahan yang sama (radius kurang lebih $1 \mathrm{~km}$ ).

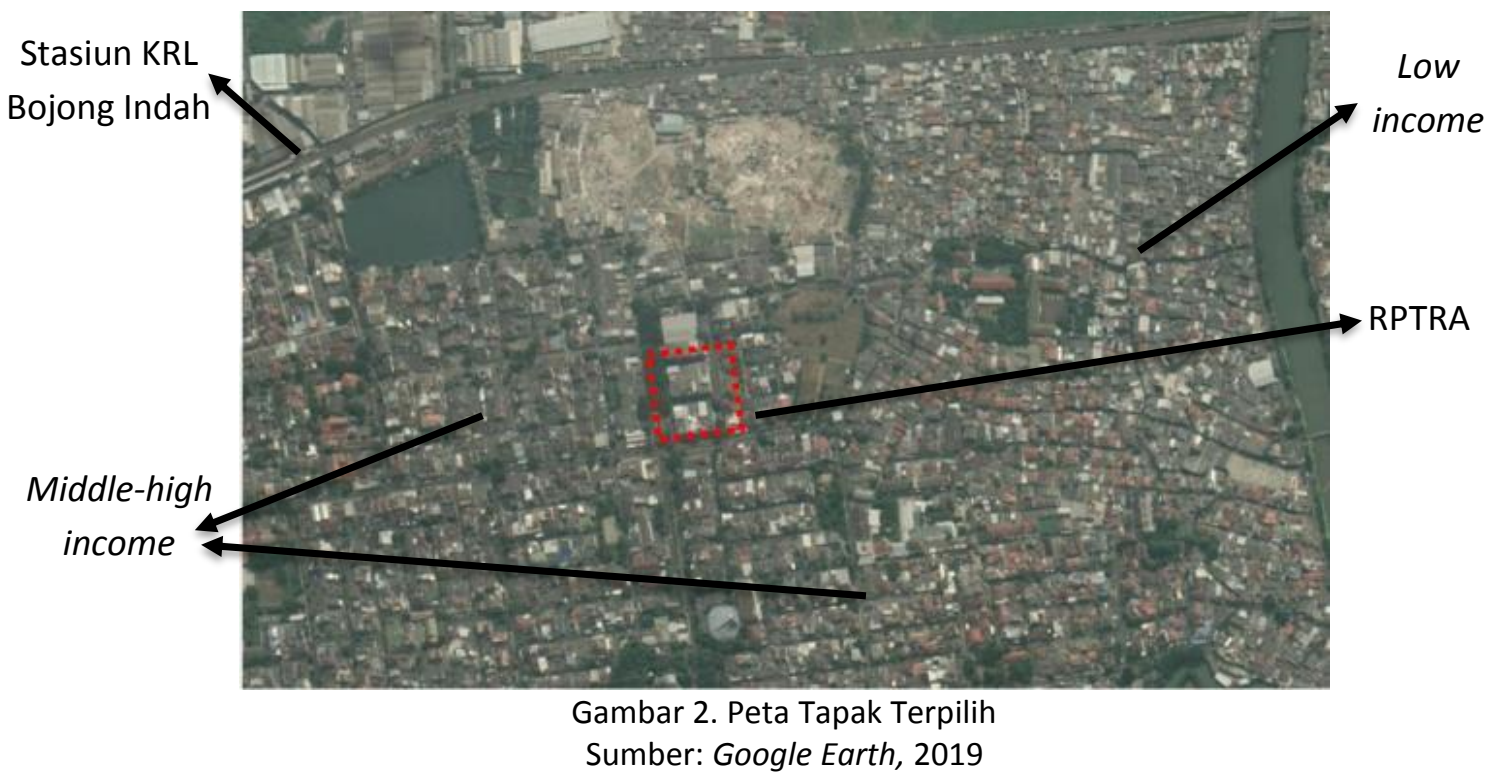

Perbedaan golongan tersebut secara fisik terlihat dari bangunan rumah dan grid hunian dilihat dari peta di Gambar 2. Kondisi lingkungan juga memperlihatkan perbedaan. Pada lingkungan middle-high income masyarakat jarang sekali terlihat di depan rumah untuk sekadar duduk atau mengobrol. Hal ini dikarenakan arsitektur rumah dan lingkungan yang tidak mendukung hal ini. Berbeda dengan lingkungan low income yang masyarakat selalu terlihat berbincang maupun sekadar duduk.

Dari hasil observasi, pada kawasan ini aktivitas bermain dominan dilakukan oleh anak-anak dari lingkungan low income. Pada Gambar 3 terlihat fenomena anak harus menyebrang jalan terlebih dulu untuk bermain di lapangan perumahan hunian middle-high income, ditambah 
dengan anak-anak yang bermain di jalan. Fenomena ini menyatakan bahwa mereka kekurangan lahan bermain di tengah kepadatan hunian mereka meskipun sudah terdapat RPTRA.

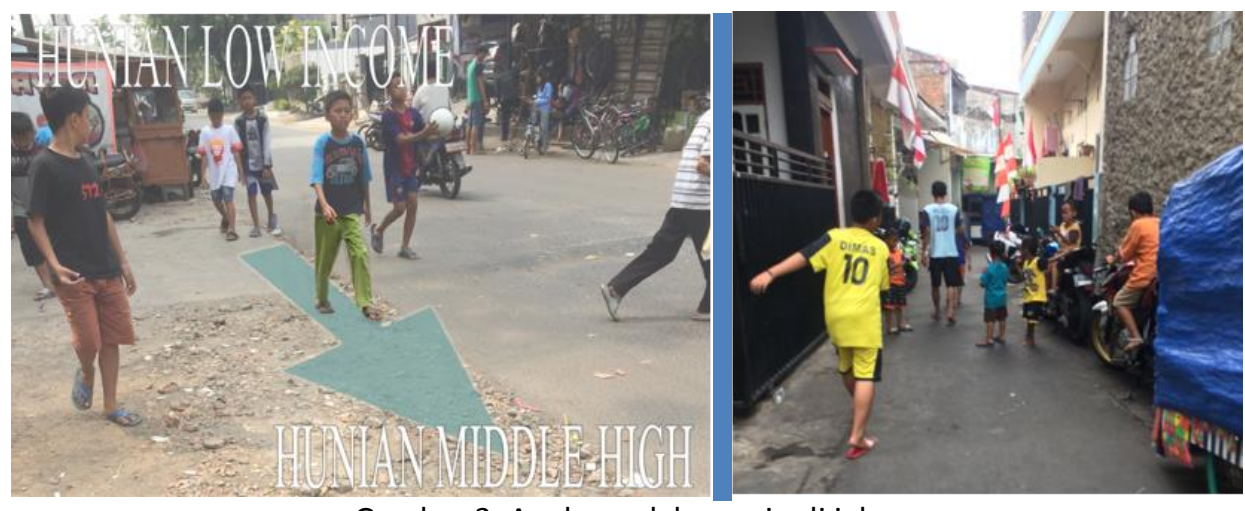

Gambar 3. Anak- anak bermain di jalan Sumber: Penulis, 2019

Selain itu, Pedagang Kaki Lima merupakan salah satu sumber kehidupan dari masyarakat di lingkungan low income. Hal ini terlihat dari arah datang PKL dan seperti pada Gambar 4. Selain di sepanjang sungai, mereka kerap berada di zona public place (Gambar peta sebelumnya gambar berapa). Kebutuhan akan ruang berhenti sehingga tidak mengganggu jalan dibutuhkan. Sifat kesementaraan dan harus-terus-bergerak dari PKL perlu diperhatikan.
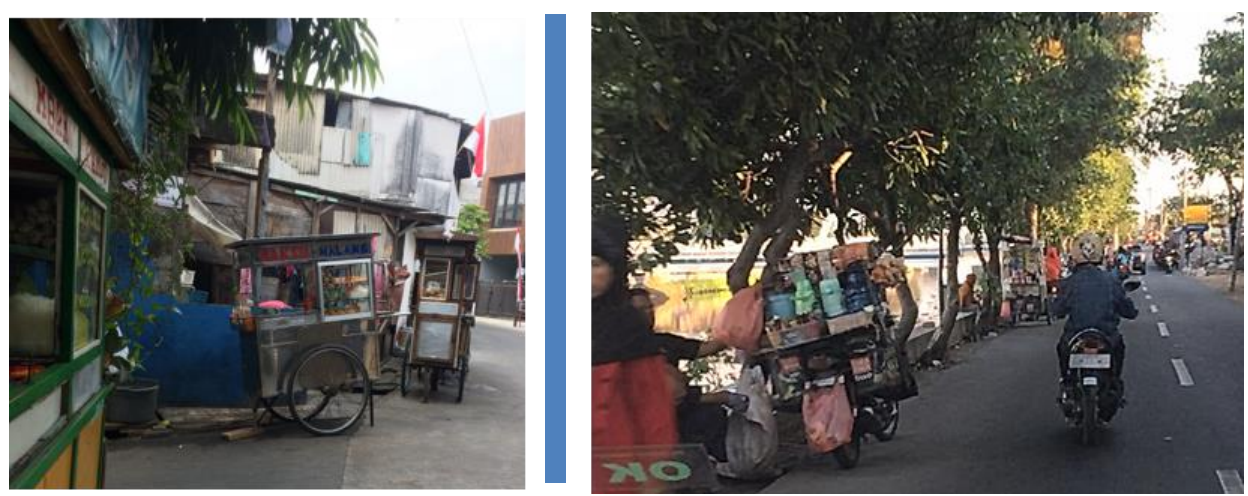

Gambar 4. Gerobak PKL yang terparkir di depan rumah warga (kiri) dan PKL yang sedang berjualan di pinggir jalan dan sungai (kanan)

Sumber: Penulis, 2019

Setelah melakukan investigasi kawasan, penulis merumuskannya dengan menggunakan 5 Logika Perancagan dari Horst Rittel. Teori yang mendukung juga dimasukkan supaya memperkuat analisa. Kerangka ini dapat semakin mempertajam diskursus perencanaan dan menentukan metode (instrumen) yang akan digunakan. Dari hasil logika ini, ada dua kata kunci yang diperhatikan yaitu kata temporer dan interaksi. Sehingga diperlukan penyatuan berbagai kegiatan (konsep temporer) dalam satu wadah dengan pendekatan psikologi sosial

\section{Konsep dan Program Ruang}

Dari hasil analisis tapak, dengan menggunakan metode analisis-sintesis, akhirnya terciptalah beberapa program ruang yang diajukan untuk wadah aktivitas di Rawa Buaya ini. Program ruang tersebut berupa program yang memang sudah ada di tapak namun belum terwadahi dengan baik, dan program yang perancang ajukan untuk muncul di kawasan. Program tersebut terbagi menjadi 4 program utama dengan beberapa program yang mendukung di dalamnya. 


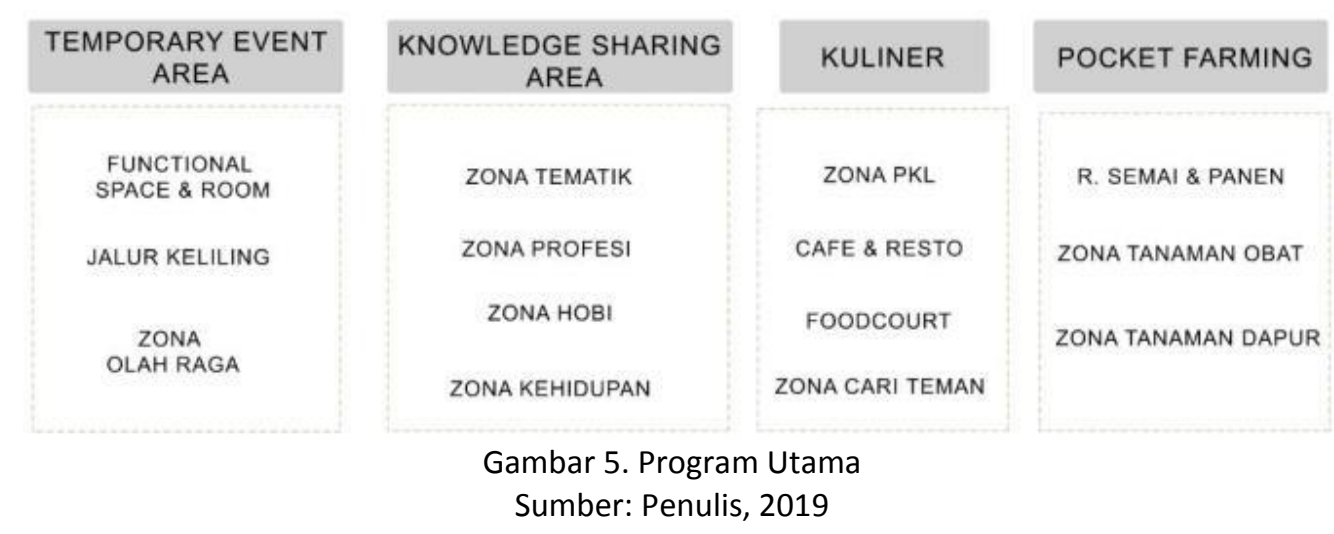

Bangunan direncanakan dengan memerhatikan karakter dari Third Place. Beberapa karakter dijadikan poin-poin utama yang dikembangkan dalam bangunan melalui program ruang dan bentukan fisik. Konsep yang digunakan adalah konsep Temporary City dengan pendekatan Psikologi Sosial. Bangunan memiliki tujuan untuk membuat pengguna saling berinteraksi. Dari konsep dan pendekatan bangunan ini, akhirnya ditemukan bahwa "kebutuhan" dapat mewujudkan interaksi dari pengguna. Untuk menciptakan kebutuhan, sehingga interaksi dapat terjadi, terdapat beberapa program ruang yang mendukung. Program ruang tersebut berupa Zona Knowledge Sharing, Zona Cari Teman, dan Zona Pocket Farming.

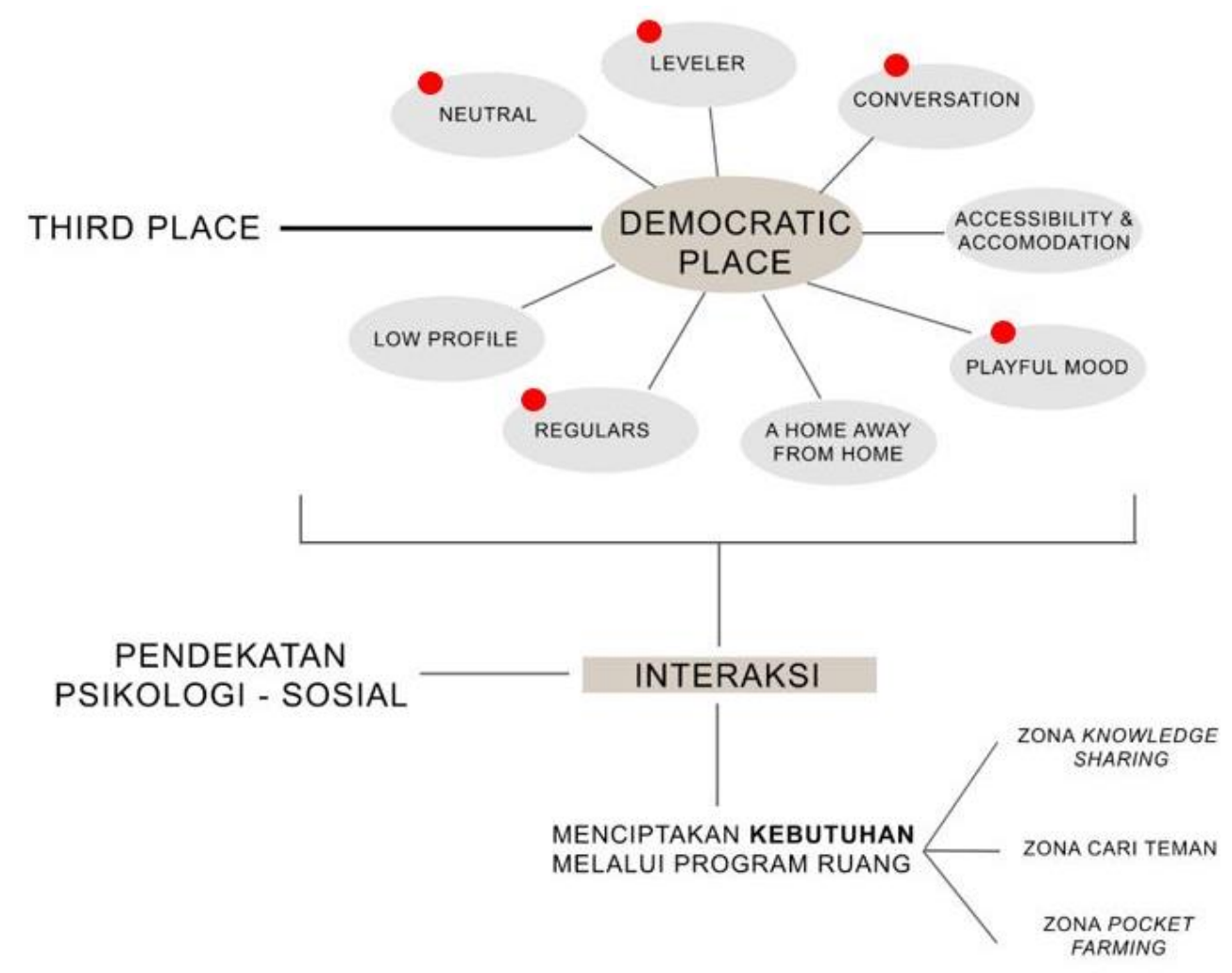

Gambar 6. Konsep Interaksi dan Kebutuhan Sumber: Penulis, 2019

Bangunan terdiri dari 4 lantai, dengan peletakkan zona sesuai dengan alur pengunjung. Zona Functional Space berada di lantai 1 dan juga lantai 4 (zona olah raga). Sedangkan zona sosial yaitu Zona Knowledge Sharing berada di lantai 2 yang dilalui oleh semua pengguna. Area komersil berada di lantai 2 dan 3, yang memaksa pengunjung dari kalangan middle-high masuk lebih dalam ke bangunan dan melewati zona sosial yang ada. Lantai 3 dan 4 diletakkan Zona 
Pocket Farming dengan memerhatikan alur pengunjung sekaligus material yang memungkinkan cahaya matahari dan udara masuk.

Tabel 1. Program Ruang

\begin{tabular}{|c|c|c|c|c|c|c|}
\hline \multicolumn{4}{|c|}{ RAWA BUAYA TEMPO.ACT. PLACE } & \multirow[b]{2}{*}{ Kegiatan } & \multirow[b]{2}{*}{ Luas } & \multirow[b]{2}{*}{ Jenis kelompok } \\
\hline & Ruang & Sifat & User & & & \\
\hline & LANTAI 1 & & & & 1690 & \\
\hline & Functional Space & publik, outdoor & SU & Kegiatan selebrasi, sosial dan bermain & 470 & crowd \\
\hline & Functional Room & Semi-privat, indoor & su & Kegiatan sosial, backstage kegiatan selebrasi & 140 & kelompok rencana \\
\hline & Loading Dock & Semi-privat, indoor & Pengelola & In \& Out barang. pemeriksaan & 85 & kelompok rencana \\
\hline & Zoaa PKL & publik, outdoor & su & Jual beli, makan minum & 423 & crowd \\
\hline & Jalur Keliling & publik, jalur & su & bazar, bermain, jogging & 264 & erowd \\
\hline 2 & LANTAI 2 & & & & 1370 & \\
\hline & Zona Knowledge Sharing & publik, indoor & Dewasa, remaja & berbineang mengenai tema yang telah diberikan & 300 & kelompok baru \\
\hline & Parkir Sepeda & publik, semi indoor & su & menaruh sepeda & 183 & \\
\hline & Foodcourt & Publik, indoor & su & Jual beli, makan minum & 144 & kelompok baru \\
\hline & Ruang duduk & Publik, indoor & SU & duduk, istirahat, mengobrol & 118 & kelompok baru \\
\hline & Cafe & publik, indoor & su & makan, minum, berbincang, mengerjakan tugas & 110 & kelompok baru \\
\hline & Musholla & publik, indoor & su & sholat, wudhu & 50 & \\
\hline 3 & LANTAI 3 & & & & 1500 & \\
\hline & Ruang Semai & publik, indoor & Dewasa, remaja & menyemai bibit & 342 & kelompok baru dan rencana \\
\hline & Zona Tanaman Obat & publik, indoor & Dewasa, remaja & menanam, menyiram, memetik & 230 & kelompok baru dan rencana \\
\hline & Café & publik, indoor & su & makan, minum, berbincang, mengerjakan tugas & 340 & kelompok baru dan rencana \\
\hline 4 & FOOD AREA & & & & 1460 & \\
\hline & Zona Tamaman Dapur & publik, indoor & Dewasa, remaja & menanam, menyiram, memetik & 550 & kelompok baru dan rencana \\
\hline & Zona Olah Raga & publik, indoor & su & Olahraga, senam & 730 & crowd \\
\hline & R. Servis (toren dan panel) & publik, indoor & Dewasa (petugas & servis & 60 & \\
\hline
\end{tabular}

Sumber: Penulis, 2019

Konsep Temporary City berusaha untuk lebih memaksimalkan sebuah ruang. Supaya ruang dapat maksimal penggunaannya, perancang mewujudkannya dengan "mewaktukan" ruang. Dengan merencanakan jadwal kegiatan berdasarkan kegiatan mereka yang sudah ada dan yang perancang ajukan. Hal ini didukung dengan perencanaan secara ruang pula. Sehingga terdapat beberapa sistem portabilitas yang dapat ditentukan penggunaannya. Pembagian ruang tersebut berdasarkan kegiatan yang sudah ada di masyarakat yaitu kegiatan bermain, selebrasi dan sosial.
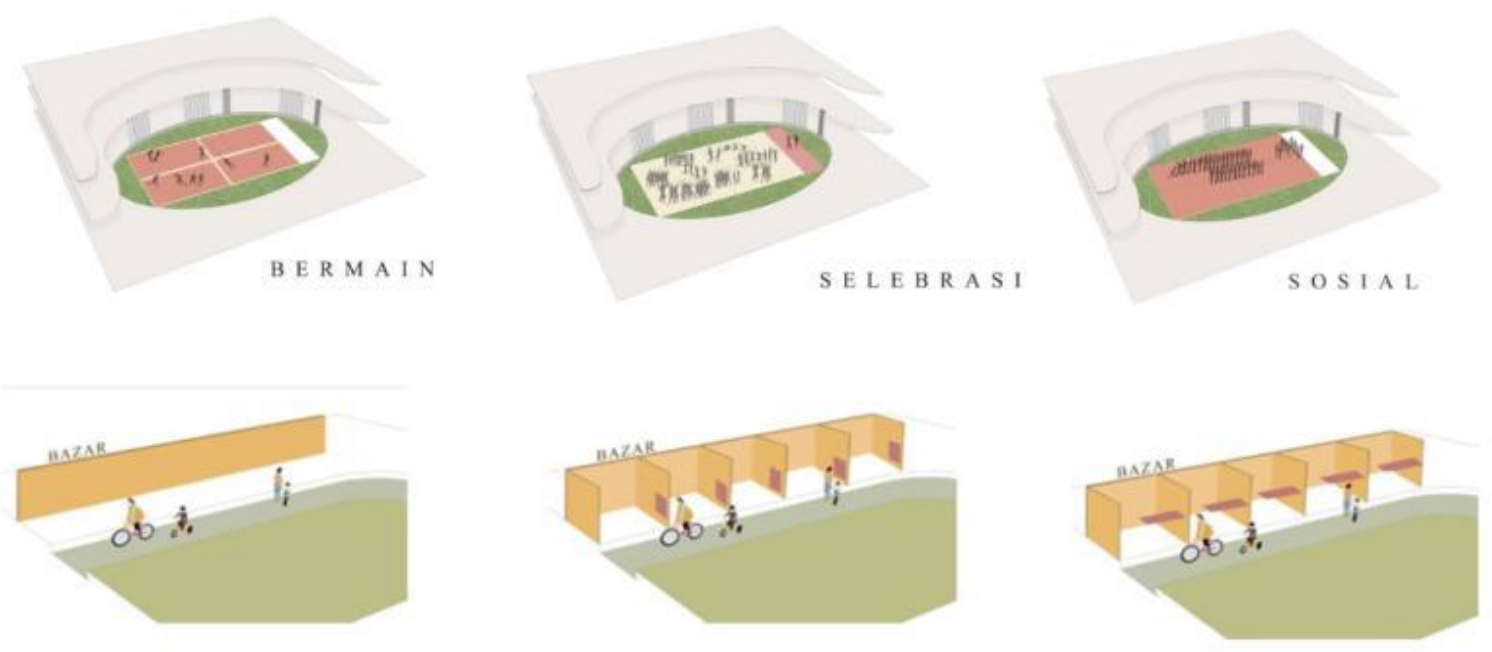

Gambar 7. Konsep Temporariness dalam program dan ruang Sumber: Penulis, 2019

Dari konsep Temporary City diambil istilah Liquid Phase. Zygmun Baunt mengatakan bahwa kita telah beralih dari Solid Phase ke Liquid Phase. Sebuah fase dimana perubahan selalu terjadi, kita tidak lagi percaya bahwa kesempurnaan dapat terjadi. Seperti cairan yang tidak dapat mempertahankan bentuknya. Metamorfosa dari istilah ini dijadikan sebuah cone yang dapat berfungsi sebagai sirkulasi, struktur (ultra-concrete) dan point of interest. Setelah melakukan sintesis terhadap tapak, denah dibuat dengan tarikan garis lengkung mengikuti cone yang telah ditentukan titiknya. 
Cone (Gambar 8) dari bangunan ini terdapat di 3 titik denah. Semua cone difungsikan untuk sirkulasi air dan listrik. Termasuk air untuk mengalirkan air hujan simpanan untuk menyiram tanaman di Zona Pocket Farming di lantai 3 dan 4. Dua diantaranya digunakan untuk sirkulasi manusia melalui tangga, dan satu untuk sirkulasi manusia melalui lift. Karena sekaligus merupakan struktur, cone memiliki bukaan untuk sirkulasi yang sesuai dengan garis seimbang cone sebagai struktur.

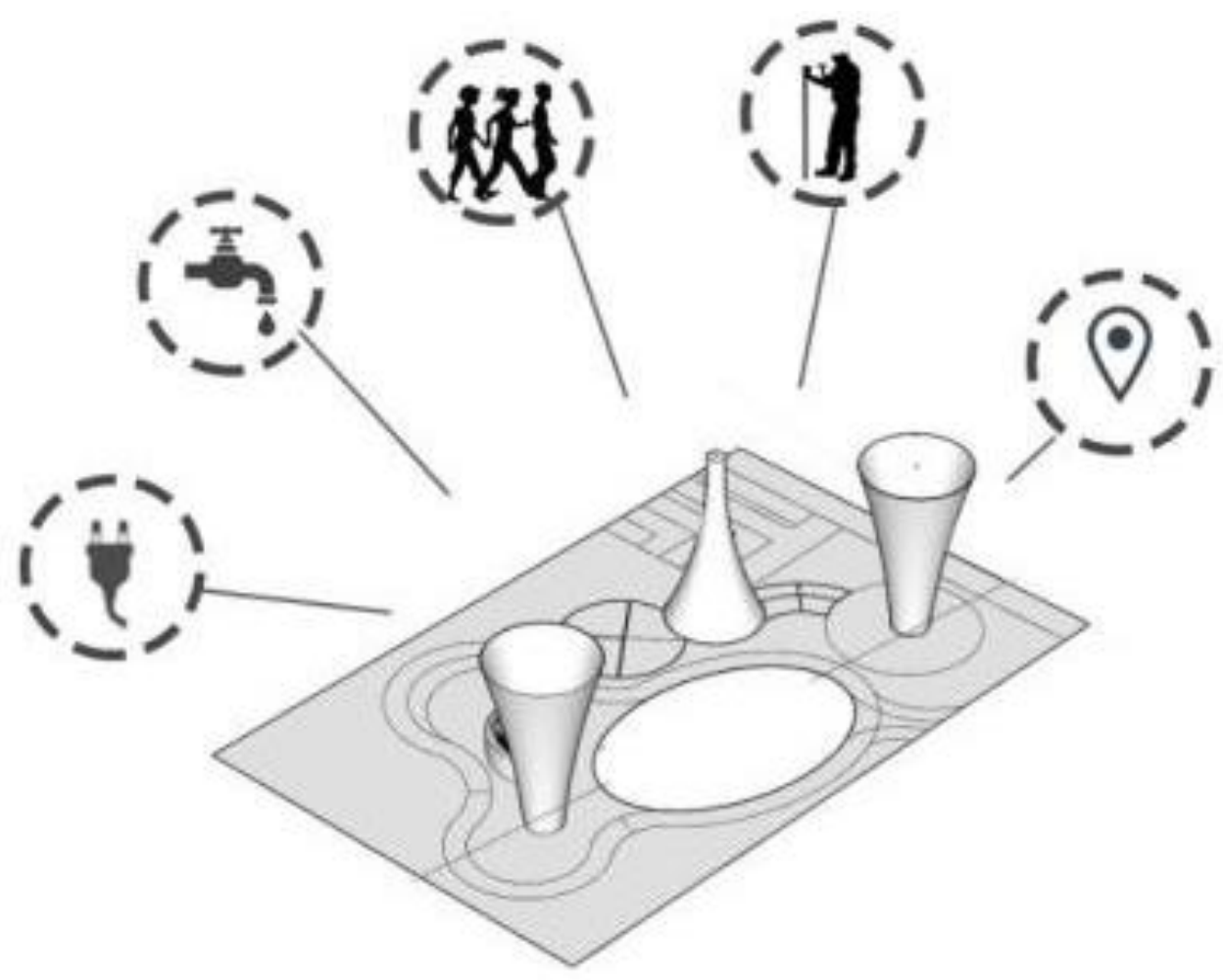

Gambar 8. Pengoptimalan Bentuk Cone Sumber: Penulis, 2019

Dari pendekatan yang dilakukan yaitu Pendekatan Psikologi Sosial, selain tercpta program ruang yang bersifat menciptakan kebutuhan berinteraksi, desain bangunan juga memerhatikan alur sirkulasi. Alur sirkulasi ini menerapkan teori Functional Distance, dimana jarak dapat mempertemukan orang-orang. Zona komersil yang ditargetkan untuk penghuni high classs diletakkan di lantai 2 dan 3, yang harus melewati Zona Knowledge Sharing terlebih dahulu. Semua sirkulasi harus selalu mempertemukan antar pengguna dari semua kalangan usia maupun ekonomi.

Kegiatan yang ditampung di Functional Space adalah kegiatan selebrasi, sosial dan bermain. Kegiatan ini didukung oleh Functional Room dan Storage yang ada. Kegiatan selebrasi berupa hiburan dengan panggung yang portable, dapat dinaik dan turunkan. Functional Room juga dapat menjadi area backstage. Kegiatan bermain juga dimasukkan sebagai hasil analisis tapak yang memperlihatkan masih kurangnya area bermain untuk anak-anak. Pola lapangan dapat dibagi menjadi 1 hingga 4 area. Area ini diletakkan di selatan tapak, supaya dapat terintergrasi dengan RPTRA yang ada di sebelah utara. Untuk kegiatan sosial (pengobatan gratis, sunatan massal dan lainnya) dan kegiatan selebrasi (backstage) diperlukan sebuah ruang fungsional tertutup. Maka dari itu disediakan sebuah ruang yang furniturenya bersifat portable. Sehingga pemanfaatn ruang dapat lebih optimal. 

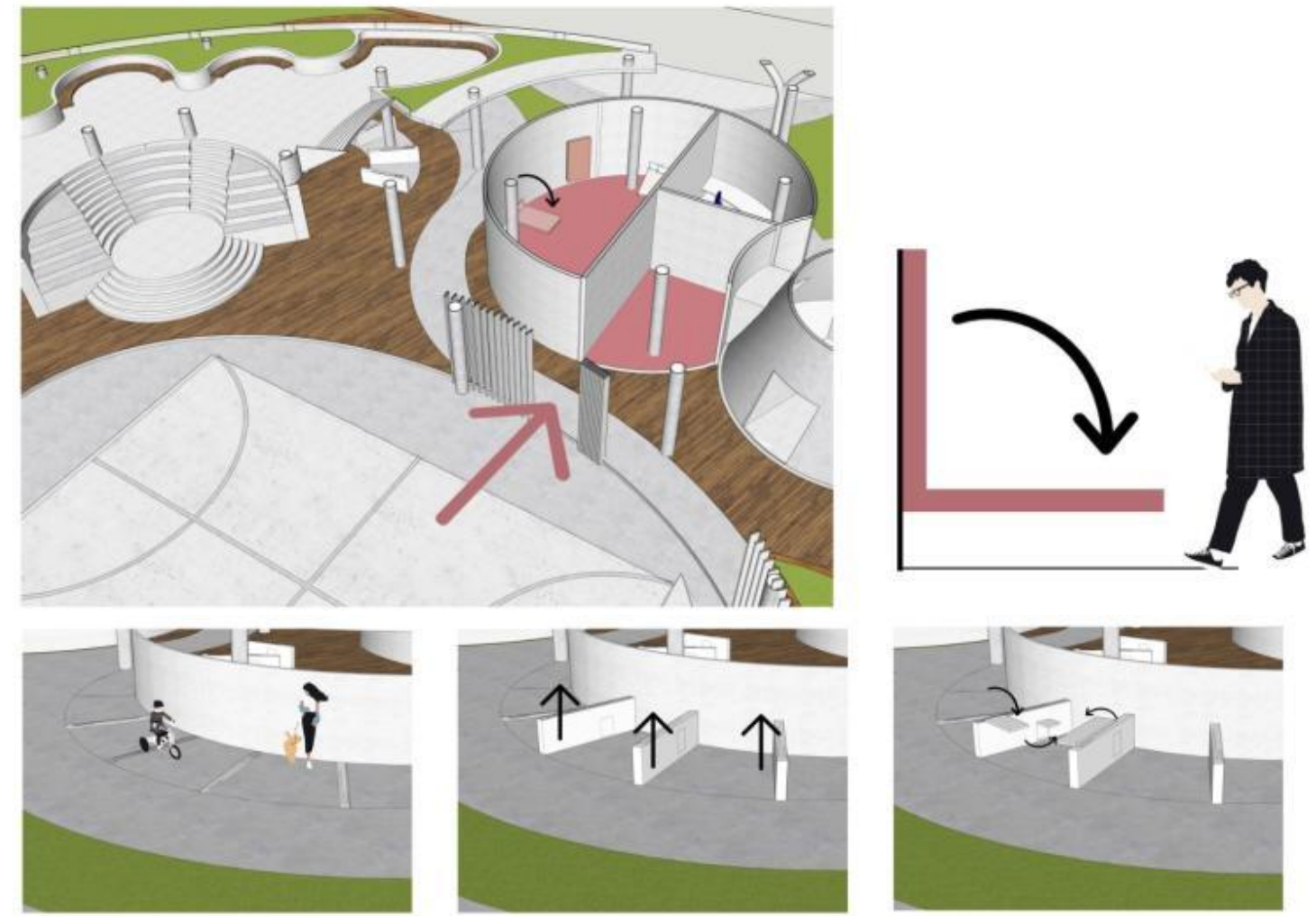

Gambar 9. Konsep Kesementaraan dalam Bentuk Ruang Sumber: Penulis, 2019

Portabilitas ruang juga terdapat di Jalur Keliling. Pada waktu normal, jalur ini berfungsi sebagai jalur sepeda dan jalur manusia (jogging). Tetapi pada waktu tertentu, jalur ini dapat berfungsi sebagai jalur bazar (Gambar 9). Kegiatan ini biasa berlangsung bersamaan dengan kegiatan selebrasi. Jalur Keliling juga memiliki ramp sampia ketinggian +2.00 untuk menuju ke Zona Knowledge Sharing di lantai 2. Terdapat juga parkir sepeda di atas ramp. Sehingga anakanak mendapatkan pengalaman ruang yang lebih beragam dibandingkan dengan kegiatan bersepeda mereka yang biasanya hanya pada jalur yang lurus. Begitu juga untuk pengguna yang sedang berolahraga (jogging).

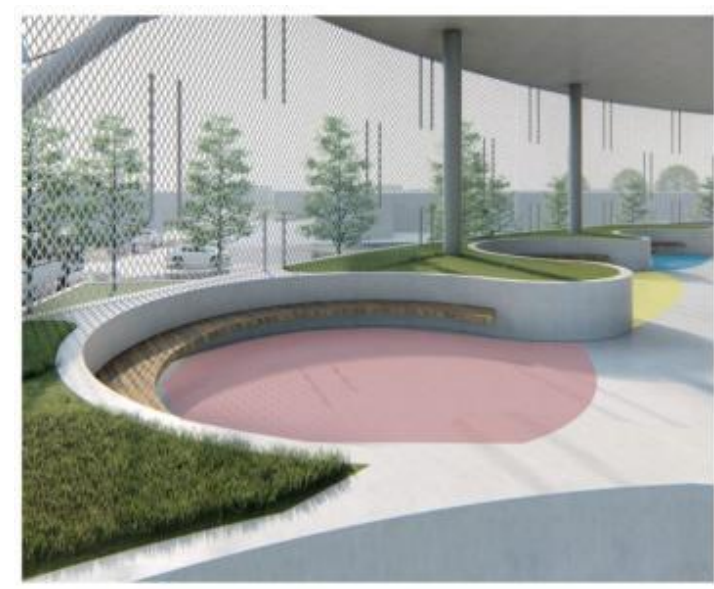

ZONA KNOWLEDGE SHARING

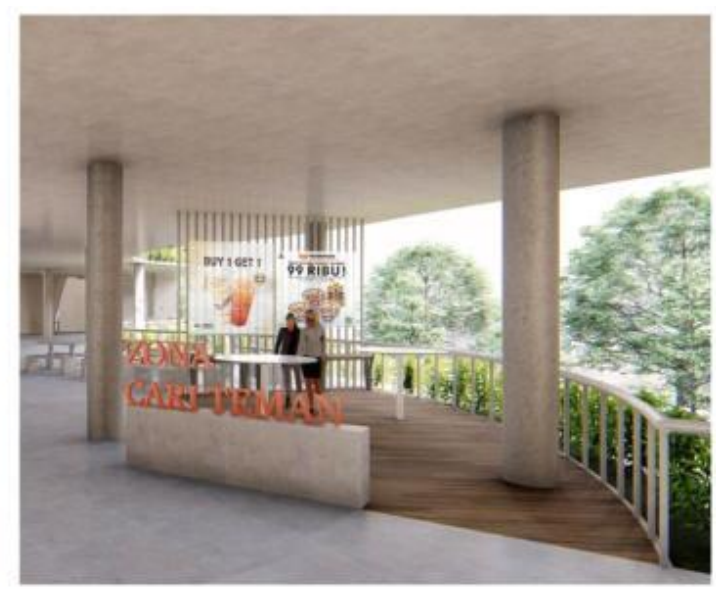

ZONA CARI TEMAN

Gambar 10. Ilustrasi Ruang Sosial

Sumber: Penulis, 2019 
Zona yang lebih bersifat sosial, selalu diletakkan di jalur yang selalu orang lewati (mengacu pada teori Functional Distance). Zona Knowledge Sharing memiliki tempat duduk yang dikelompokkan berdasarkan topik bahan pembicaraan. Regulasi pada zona ini adalah barangsiapa yang duduk di zona ini, harus mau diajak mengobrol. Untuk membnatunya diberikan signage bertuliskan tema obrolan. Zona ini direncanakan untuk menciptakan kebutuhan mengobrol antar pengguna.

Zona Cari Teman juga merupakan zona yang direncanakan untuk menjadi wadah pertemuan antar kebutuhan pengguna. Perancang memanfaatkan adanya area komersil berupa kuliner dengan menggunakan diskon. Zona ini mempertemukan orang-orang yang ingin menikmati diskon seperti buy 1 get 1 dan diskon lainnya yang membutuhkan lebih dari satu orang untuk dinikmati. Tempat duduk juga didesain lebih fleksibel untuk orang lalu lalang, sehingga zona ini tidak disalahgunakan menjadi tempat duduk santai orang berlama-lama.
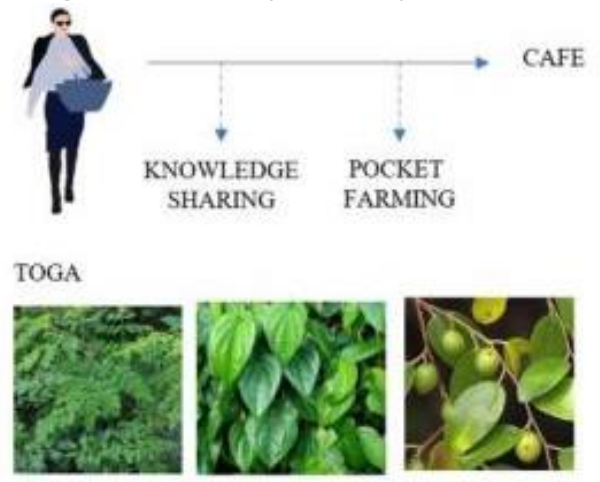

TANAMAN DAPUR DAN BUAH-BUAHAN
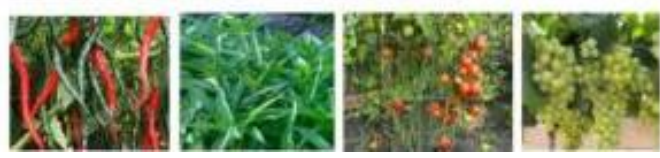

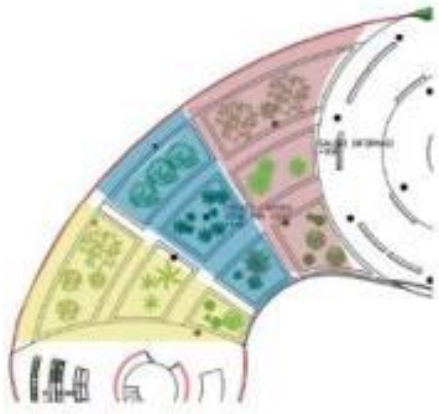

ZONA TNM. OBAT

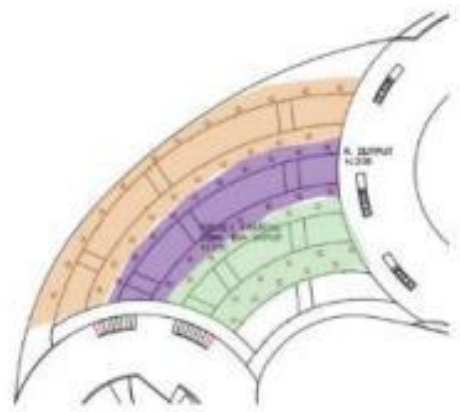

ZONA TNM. DAPUR

Gambar 11. Program Pocket Farming

Sumber: Penulis, 2019

Pada lantai paling atas ditempatkan zona Pocket Farming. Sehingga area penerimaan cahaya matahari dapat lebih maksimal. Area ini juga diperhatikan sirkulasinya sehingga teori Functional Distance dapat dicapai. Karena zona ini terdiri dari 2 lantai plus mezanine, lantai menggunakan material yang ringan sekaligus tembus cahaya yaitu wiremesh. Sistem vertical farming adalah menggunakan pipa PVC yang dilubangi dengan pipa air di dalamnya. Pengurus dari pocket farming yang dibuat adalah warga setempat. Ada 12 RW yang menjadi masingmasing kelompok. Kemudian dibentuk zona tanaman, yang satu zona diurus oleh 2 kelompok. Urutan kelompok juga diacak tiap bulan. Sehingga dengan berkebun, tercipta pula interaksi sosial antar warga. 


\section{Sirkulasi dan Material}

Untuk dapat memberikan sirkulasi cahaya matahari dan udara yang dapat tesebar di seluruh ruang dalam, bangunan dirancang terbuka. Dengan hanya dinding masif di sedikit area seperti toilet, musholla dan dapur restoran atau kafe. Selebihnya dipilih bentuk atap yang mampu menyelubungi bangunan. Pemilihan atap yang menyatu dengan fasad seperti gambar di bawah juga memberikan kesan dinamis untuk third place. Sehingga karakter third place yaiu playful mood lebih dapat terasa.
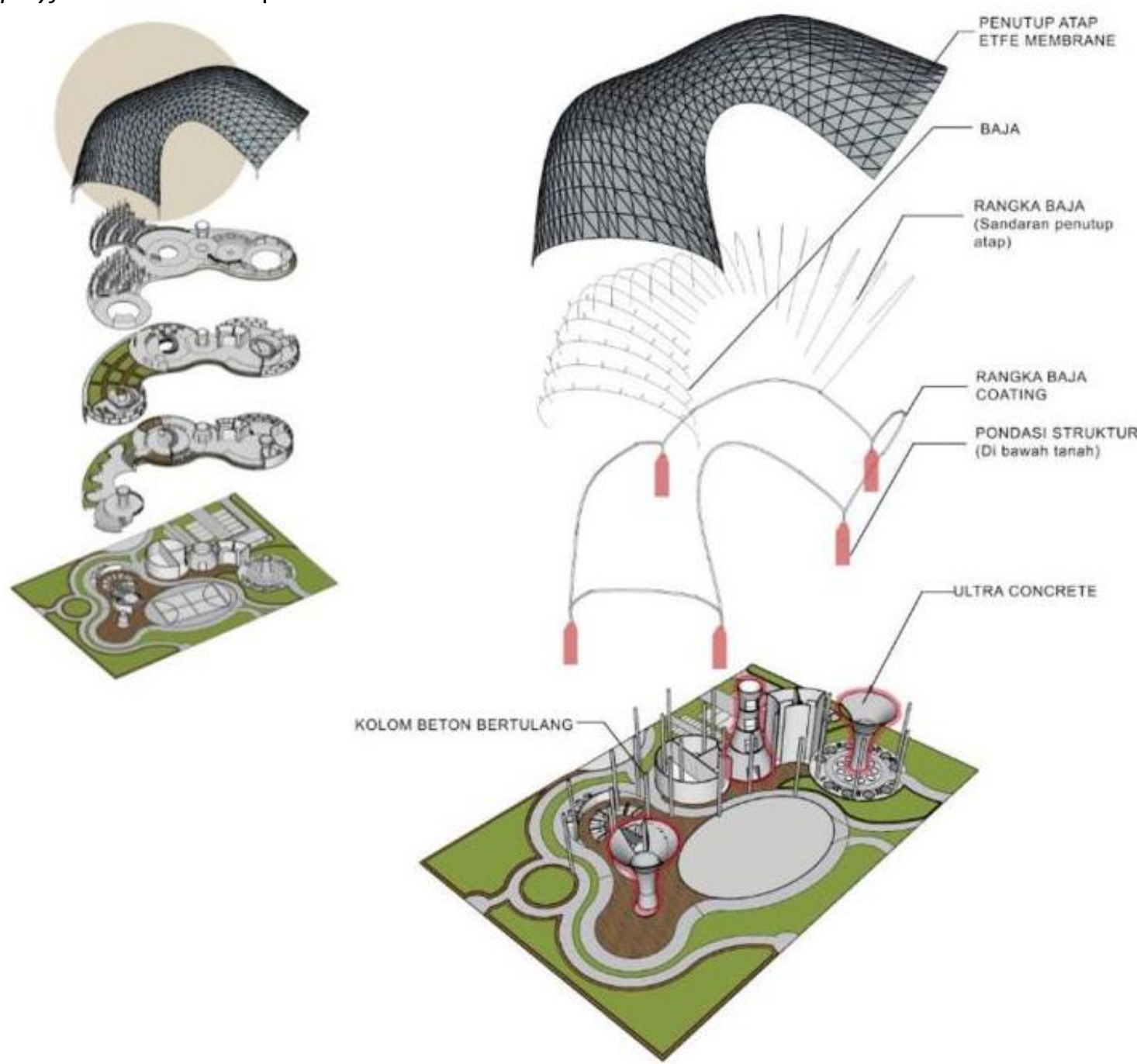

Gambar 12. Axonometri Struktur

Sumber: Penulis, 2019

Penutup atap adalah membran ETFE. Material ini dapat memasukkan sinar matahari tanpa panas dari matahari. Sehingga baik digunakan karena bagian atas bangunan adalah pocket farming yang membutuhkan cahaya matahari. Sistem air hujan dialirkan melalui kolom-kolom yang ada dan sebagian dialirkan ke pengolahan air hujan untuk digunakan sebagai air penyiraman vertical farming.

\section{KESIMPULAN DAN SARAN}

Manusia hanya akan berinteraksi apabila memiliki suatu kebutuhan. Dengan adanya interaksi, manusia dapat minimal saling sadar akan keberadaan satu sama lain hingga mengenal satu sama lain dengan baik. Kebutuhan ini dapat diterjemahkan berupa program ruang yang diwujudkan melalui arsitektur. Seiring berjalannya waktu, kita perlu memikirkan pula efektivitas sebuah ruang yang kita tidak akan pernah tau bagaimana kedepannya. 
Untuk itu, kita perlu peka dalam memastikannya ketika kita menganalisis tapak beserta kondisi sosial warganya. Menjadi tugas seorang perencana dan perancang untuk dapat menciptakan atau memicu kebutuhan tersebut untuk muncul dan mewadahinya. Konsep Temporary City dapat diperhatikan untuk mengoptimalkan sebuah ruang. Karena pada dasarnya tidak ada yang namanya keabadian. Semua hanya bersifat temporer, yang datang dan pergi.

\section{REFERENSI}

Alexander, C. (1964). Notes on The Synthesis of Form. Harvard University Press.

Armand, A. (2017). Arsitektur yang Lain. Gramedia Pustaka Utama.

Aronson, E. dkk. (2010). Social Pyschology. Pearson.

Bishop, P. dkk. (2012). The Temporary City. Routledge.

Badan Pusat Statistik. (2017). Statistik Daerah Provinsi DKI Jakarta.

McLaren, D. dkk. (2015). Sharing Cities. The MIT Press.

Guy G, (2013), Open Architecture: Guy Geier at TEDxTimesSquare. Diunduh 17 Agustus 2019, $<$ https://www.youtube.com/watch?v=jQwXejQwTGw

Oldenburg, R. (1989). The Great Good Place. Da Capo Press.

Rittel, H. (2010). The Universe of Design. Routledge

Wikipedia, 2017, DKI Jakarta. Diunduh 22 Juli 2019 https://id.wikipedia.org/wiki/Daerah Khusus Ibukota Jakarta 